\section{Oxygen concentrators and the practice of anaesthesia}

Robert M. Friesen MD FRCPC
With the exception of domiciliary oxygen, the majority of oxygen for clinical use is supplied by large-scale liquefaction. This process is commonly referred to as the cryogenic distillation of air. Oxygen is then supplied to the facility requiring it in either bulk liquid containers or compressed gas cylinders. An alternative oxygen source, especially for existing hospital pipeline systems, has been available in Manitoba since late 1987. On-site production of oxygen is made possible by the use of molecular sieve technology. Molecular sieves allow for the selective adsorption of the components of air. This paper will review the process of oxygen generation by oxygen concentrators as well as the implications of oxygen supplied by an oxygen concentrator to the provision of anaesthesia and other patient therapies.

Selective adsorption of the components of air by naturally occurring substances, zeolites, has been known for more than $60 \mathrm{yr}$. Although zeolites occur naturally, industrial research has resulted in synthetic molecular sieves of more uniform consistency. Zeolite has a natural affinity for water, which is released on heating. The Greek derivation for zeolite is "boiling stone." Synthetic zeolite used for the production of oxygen consists of a rigid framework of silica and aluminium with an extra cation to make up the positive charge deficit in the structure. ${ }^{1}$ Oxygen molecular sieves utilize calcium or sodium as an additional cation. Molecular sieves are available commercially in pellet form utilizing an inert binder.

The physical properties of the gases which come in contact with zeolite (referred to as the adsorbent) determine their relative adsorption to its surface. The major components of air have molecular diameters which are small enough to pass through the pores of a molecular sieve $^{1}$ (Table I).

Calcium (or sodium) as an additional cation confers a net positive charge on the pore. The electronic properties of the constituents of the air presented to the zeolite molecular sieve will then determine the strength of the adsorption process. These properties include polarisability, dipole movement and quadripole movement. The observed adsorption energies ${ }^{1}$ are summarized in Table II. The product gas consists primarily of oxygen with some argon.

Adsorption efficiency can be enhanced by a modest increase in operating pressure. The majority of commer-
TABLE I Relative dimensions for molecular sieves

\begin{tabular}{ll}
\hline Zeolite pore & $4.3 \AA$ \\
Molecular diameter oxygen & $3.4 \AA$ \\
Molecular diameter nitrogen & $3.6 \AA$ \\
Molecular diameter argon & $3.3 \AA$ \\
\hline
\end{tabular}

$\AA=$ Angstrom units $=1 \times 10^{-8} \mathrm{~cm}$.

TABLE II Zeolite molecular species adsorption

\begin{tabular}{lll}
\hline & & Relative scale \\
\hline Water & $\left(\mathrm{H}_{2} \mathrm{O}\right)$ & +++++ \\
Carbon dioxide & $\left(\mathrm{CO}_{2}\right)$ & ++++ \\
Nitrogen & $\left(\mathrm{N}_{2}\right)$ & +++ \\
Oxygen & $\left(\mathrm{O}_{2}\right)$ & ++ \pm \\
Argon & $(\mathrm{Ar})$ & \pm \\
\hline
\end{tabular}

cially available oxygen concentrators enhance their efficiency by using a pressure swing adsorption cycle (PSA). Nitrogen-oxygen adsorption dynamics are accomplished by having two columns of zeolite operating in sequence but with their cycles out of phase by one half a cycle duration. This ensures a constant output of oxygen. Regeneration of each zeolite column is accomplished by "bleeding off' adsorbed nitrogen from the zeolite bed at the end of each cycle and then briefly flushing with a small quantity of the just-generated oxygen. Alternatively, zeolite column regeneration can be accomplished by the application of a brief negative pressure at the end of each cycle.

The components of an oxygen concentrator include a fresh air intake (appropriately sized and filtered), a compressor with air cooler and storage tank, while housed within the actual unit are several zeolite molecular sieve beds as well as a number of controlling devices (Figure 1). A product gas storage tank (primary supply) is usually located in the proximity to the other compressed oxygen sources. Further technological refinements are expected to alter this configuration somewhat.

The United States Pharmacopeia (USP) defines oxygen as containing not less than $99.0 \%$, by volume, of oxygen. ${ }^{2}$

From the Department of Anesthesia, University of Manitoba, St. Boniface General Hospital, Winnipeg, Manitoba. 


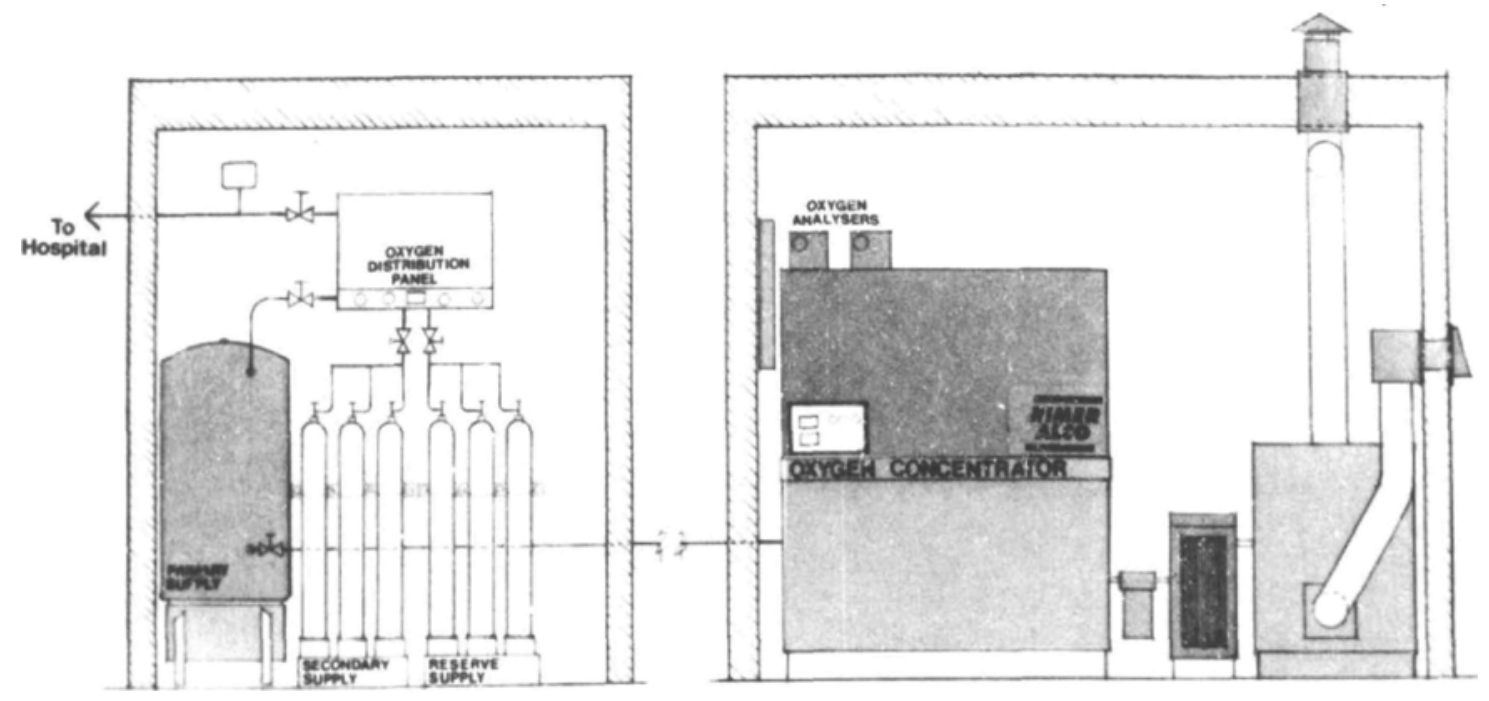

Mudical Gas Supply froom

Oxygan Concentrator froom Elevation

FIGURE 1 Typical oxygen concentrator installation.

TABLE III Comparison of cryogenic and PSA oxygen (allowable constituents)

\begin{tabular}{lll}
\hline & Oxygen 99 (USP) & Oxygen 93 (USP) \\
\hline Oxygen & $\geq 99 \%$ & $>90 \dagger \leq 96 \%^{*}$ \\
Carbon monoxide & $5 \mathrm{ppm}$ & $5 \mathrm{ppm}$ \\
Carbon dioxide & $100 \mathrm{ppm}$ & $100 \mathrm{ppm}$ \\
Methane (or equivalent) & $100 \mathrm{ppm} \odot$ & $25 \mathrm{ppm}$ \\
Nitrous oxide & $5 \mathrm{ppm}$ & $5 \mathrm{ppm}$ \\
Anaesthetic agents & $0.1 \mathrm{ppm}$ & $0.1 \mathrm{ppm}$ \\
Oil particulate & $1 \mathrm{mg} \cdot \mathrm{m}^{-3}$ & $1 \mathrm{mg} \cdot \mathrm{m}^{-3}$ \\
Sulphur dioxide & $1 \mathrm{ppm}$ & $1 \mathrm{ppm}$ \\
Total halogenated & $5 \mathrm{ppm}$ & $5 \mathrm{ppm}$ \\
$\quad$ hydrocarbons & $1 / 2 \mathrm{TLV}$ & $1 / 2 \mathrm{TLV}$ \\
Other components or & & \\
contaminants & & \\
\hline
\end{tabular}

* Balance argon and nitrogen.

†CSA Z305.6 oxygen concentrator minimum performance specification oxygen $\geq 93 \%$ by volume.

ppm - parts per million.

OMaximum allowable limit proposed to decrease to $50 \mathrm{ppm}$ in future standards.

TLV - threshold limit value as defined by the American Conference of Governmental and Industrial Hygienests (ACGIH).

The product gas produced by a molecular sieve process has been defined as oxygen $93 \%$. It contains not less than $90 \%$ and not more than $96 \%$, by volume, of oxygen, the remainder consisting mostly of argon and nitrogen. Oxygen, 93\%, was defined in the USP based on limitations of molecular sieve technology until $1984 .^{2}$

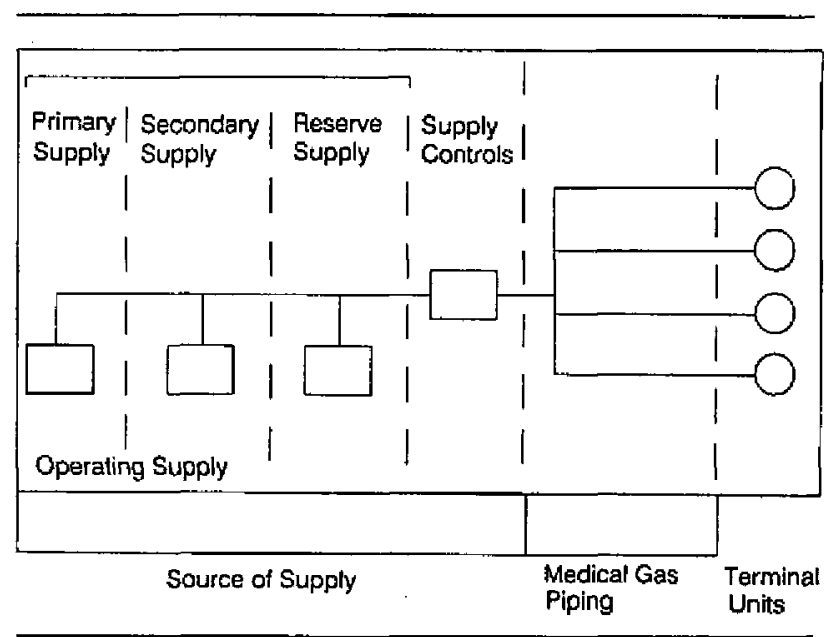

FIGURE 2 Hospital medical gas piping system.

A comparison of the composition of oxygen $99^{3}$ and oxygen $93 \%$ as well as the maximum allowable limits for the other trace substances listed is shown in Table III. The use of oxygen concentrators to provide a primary supply of oxygen requires that each hospital adopt oxygen 93 (USP) into its formulary.

Standards for hospital medical gas piping systems have been previously addressed by the Canadian Standards Association. ${ }^{3}$ Individual hospitals may vary somewhat in design but all provide for a primary, secondary and reserve supply of oxygen (Figure 2). Sizing of supply is based on 
TABLE IV Hospital oxygen source of supply

\begin{tabular}{|c|c|c|}
\hline & CSA Z305.1 & $\operatorname{CSA} Z 305.6^{*}$ \\
\hline Primary supply & $\otimes$ & $2 \times$ average flow rate \\
\hline Secondary supply $\dagger$ & $\otimes$ & $\begin{array}{l}2 \text { day's average oxygen } \\
\text { demand } \odot\end{array}$ \\
\hline Reserve supply $\dagger$ & $\begin{array}{l}\text { average one } \\
\text { day's supply }\end{array}$ & $\begin{array}{l}1.5 \text { day's average oxygen } \\
\text { demand } \odot\end{array}$ \\
\hline
\end{tabular}

*Preliminary proposal.

○Local conditions such as geographic location or isolation may require greater secondary and reserve supplies.

† Secondary and reserve supplies are oxygen 99 for both supply systems.

QSized according to health care facility.

the health care facility size (number of beds), acuity of care, and predicted average peak demand. The operating source of supply for oxygen is composed of primary and secondary supplies. The primary supply is utilized in most circumstances where centrally supplied oxygen is required. In the event of peak usage, the hospital secondary supply might be required and as such is not an abnormal event. Excessive reliance on a hospital's secondary oxygen supply is not advocated. The reserve supply is utilized only if there is a failure of the operating supply.

Presently, the Canadian experience with oxygen concentrators has been as a primary source of supply of oxygen (Figure 1). In most cases, an oxygen concentrator has been added-on to an existing medical gas pipeline system. Addition of an oxygen concentrator to an existing system, in effect, increases the individual hospital's operating supply for oxygen. The present CSA standards for conventional medical gas piping systems ${ }^{3}$ are compared with those proposed ${ }^{4}$ for health facilities which utilize an oxygen concentrator as a primary source of supply in Table IV.

Canadian experience with the use of oxygen concentrators for the provision of medical oxygen is limited compared with other countries. ${ }^{5-9}$ Earlier versions of the oxygen concentrator could not supply the volume, flow rates or consistency of delivered oxygen supply that present technology allows. There are a number of areas of interest and possibly concern to the anaesthetist who practices in a hospital where an oxygen concentrator serves as the primary oxygen supply source.

International ${ }^{10-12}$ and local experience has shown oxygen concentrators can provide a reliable supply of oxygen. In Manitoba, oxygen concentrators have been demonstrated to provide a consistent oxygen supply $\geq 95 \%$. The remainder of the product gas is argon with trace amounts of nitrogen. Duplicate oxygen monitors continuously monitor oxygen concentrator output and initiate the isolation of the concentrator from the hospital oxygen pipeline system if the oxygen concentration in the product gas should fall. The Servomex model 571 oxygen monitor used in Manitoba installations has an accuracy of $\pm 0.3 \%$ for oxygen.

The CSA standard Z305.1 ${ }^{3}$ provides for medical gas piping specificity. Oxygen 99 and oxygen 93 are different medical drug preparations as defined by the USP. ${ }^{2}$ As the secondary and reserve oxygen supply systems in a hospital utilizing an oxygen concentrator are serviced with oxygen 99, some mixing of these two gases will occur. Experience has shown this to be clinically insignificant. A ruling by Health and Welfare Canada as to the appropriateness of mixing oxygen 93 and oxygen 99 also supports such practice. As previously, the monitoring of oxygen concentration at end use terminals is important. Testing and certification procedures must be modified to account for the presence of an oxygen concentrator. ${ }^{4}$

The majority of existing oxygen therapies are dictated by patient responses and not by minor changes in inspired oxygen concentration. The American College of Surgeons describes an adequate inspired concentration of oxygen for Advanced Trauma Life Support as greater than $85 \% .^{13}$

Campbell ${ }^{14}$ and Leigh ${ }^{15}$ have described the requirements for high volume, consistent oxygen concentration therapy. The Ventimask 3 Oxygen Mask ${ }^{\circledR}$ manufactured by AirShields Vickers utilizes the venturi principle of air entrainment with a pre-determined flow of oxygen to administer a specific oxygen concentration to a spontaneously breathing patient. Table $\mathrm{V}$ summarizes the effect of utilizing oxygen sources other than oxygen 99 on the final product gas. The variation in delivered oxygen concentration is within the one percent variation limit proposed by Campbell. ${ }^{14}$

Modern anaesthetic machines which conform to CSA standards ${ }^{16}$ are not adversely affected when supplied by an oxygen concentrator. Ohmeda, Drager and Penlon manufacturers were notified of the use of oxygen concentrators in Manitoba before the tendering process for the Manitoba Anaesthetic Upgrade Program. ${ }^{17}$ Anaesthetic machines may utilize some form of $\mathrm{N}_{2} \mathrm{O}-\mathrm{O}_{2}$ proportioning device to prevent the inadvertent administration of. hypoxic gas mixtures to the patient. Provision of oxygen 93 rather than oxygen 99 to either North American Drager's oxygen ratio monitor controller (ORMC) ${ }^{\circledR}$ or the Ohmeda link-25 system does not result in an hypoxic inspired oxygen concentration. The Ohmeda link-25 system actually increases oxygen flow, if nitrous oxide flow is inadvertently increased, to maintain a minimum $\mathrm{N}_{2} \mathrm{O}-\mathrm{O}_{2}$ flow ratio of 3:1.

Argon's viscosity is similar to that of oxygen but it is more dense $\left(1.78 \mathrm{~kg} \cdot \mathrm{m}^{-1}\right.$ versus $\left.1.43 \mathrm{~kg} \cdot \mathrm{m}^{-1}\right) .{ }^{18}$ The presence of argon (less than seven percent) in oxygen does not alter its flow characteristics. 
TABLE $V$ Effect of altered oxygen flow concentrations on the calculated performance of the Ventimask -3 oxygen mask

\begin{tabular}{|c|c|c|c|c|c|}
\hline \multirow{2}{*}{$\begin{array}{l}\text { Desired } \mathrm{O}_{2} \\
\text { admin. \% }\end{array}$} & \multirow[b]{2}{*}{$\mathrm{O}_{2}$ flow $^{\prime}$} & \multirow[b]{2}{*}{ Total flow $w^{1,2}$} & \multicolumn{3}{|c|}{ Calculated inspired $\mathrm{O}_{2} \%^{3}$} \\
\hline & & & $O_{2}(99)$ & $\mathrm{O}_{2}(95)$ & $O_{2}(93)$ \\
\hline 24 & 3 & 78 & 24 & 23.8 & 23.8 \\
\hline 28 & 6 & 66 & 28 & 27.7 & 27.6 \\
\hline 35 & 12 & 67 & 35 & 34.2 & 33.9 \\
\hline
\end{tabular}

'Flows as per Ventimask - 3 oxygen mask ${ }^{\circledR}$ specifications.

${ }^{2}$ Total flow $=\mathrm{O}_{2}+$ entrained flow.

${ }^{3}$ Calculated inspired $\mathrm{O}_{2}=\mathrm{O}_{2}$ content (flow volume)/total flow volume.

${ }^{4}$ Assumes entrained air $\mathrm{FIO}_{2}=0.21$.

Infra red, galvanic cell and paramagnetic monitoring technologies are not adversely affected by the presence of argon. Gas mass spectrometer analysis of anaesthetic gases may require "programming" for increased concentrations of argon. This is similar to the previous experience of Williams and Benson ${ }^{19}$ with helium.

Argon is an anaesthetic at between 15.2-16.9 atmospheres absolute. ${ }^{20}$ By comparison, oxygen is a potential convulsant at 3 atmospheres absolute and an anaesthetic at 15 atmospheres absolute. There are no known physiological effects from either long- or short-term exposure to low concentrations of argon. ${ }^{20,21}$

Low flow or closed circuit anaesthetic techniques represent a special problem with the use of oxygen supplied by molecular sieve technology. Argon accumulation occurs as a necessary consequence of selective oxygen uptake. The major determinants of argon accumulation are the circuit fresh gas flow and the patient's rate of oxygen consumption. ${ }^{18,22}$ The concomitant administration of nitrous oxide further complicates this process. Once again the importance of circuit oxygen concentration monitoring cannot be over-emphasized.

Unpublished data from hospital installations in the United Kingdom, the American Military and Rimer Alco (one of several oxygen concentrator manufacturers), as well as published data ${ }^{11}$ demonstrate that the zeolite molecular sieve is a very effective filter for most potential air pollutants. Possible contaminants or sources tested include motor vehicle exhaust, jet aircraft air compression "bleeds," ${ }^{21}$ ethylene oxide, sulphur dioxide, numerous, hydrocarbons as well as agents usually reserved for chemical warfare. Agents introduced into the air inlet of the test oxygen concentrators included live chemical warfare agents (mustard gas, sarin, hydrogen cyanide, cyanogen chloride) as well as dimethyl methylphosphonate, methyl chloride and perfluoroisobutylene. The molecular sieve did not allow any of these agents to transgress it and thus contaminate the product gas. It has been suggested that gross contamination of the molecular
TABLE VI Cost summary - oxygen concentrators in Manitoba

\begin{tabular}{ll}
\hline Hospitals & 22 \\
Hospital size & $11-152$ beds \\
Total \# patient beds & 929 \\
Capital costffacility & $\$ 22,265-\$ 342,895$ \\
Pay back period $\dagger$ & $1.6-5.0$ years \\
Projected savings $(13$ years)* & $\$ 6,463,872$ \\
\hline
\end{tabular}

†Mean payback period 3.6 years.

*Assumes a 6\% increase in non-capital costs and a stable cryogenic oxygen market.

sieve by agents which adhere to it irreversibly will result in decreased efficiency of the sieve. This condition would be detected by the in-line oxygen monitor.

The major impetus for the refinement of molecular sieve oxygen concentrators has been the lack of reliability of supply, as well as the cost of oxygen in many parts of the world. Oxygen concentrators are presently utilized to provide medical grade oxygen in a wide spectrum of applications. Some of these include military applications (mobile hospitals, fighter aircraft, ${ }^{23}$ naval vessels) as well as remote medical facilities throughout the world and most recently in North America. The economics of oxygen concentrators have been most favourable. ${ }^{12,24}$

Excessive increases in the cost of supply of oxygen in the mid-1980s provided a stimulus for the Province of Manitoba to seek alternative oxygen sources. With the cooperation of a local manufacturer/supplier of oxygen concentration technology (Rimer Alco, Morden, Manitoba), a pilot project was undertaken by the Manitoba Health Services Commission. There are presently 22 hospitals in the Province of Manitoba whose primary oxygen source is an oxygen concentrator. Table VI summarizes the associated costs and projected savings of these installations.

A further benefit recognized by the installation of oxygen concentrators has been increased competition in the oxygen supply market place. Hospital purchasing agents have noted decreases in quotations for compressed 
or liquid primary oxygen 99 supplies as they considered tendering for oxygen concentrator installation. An analysis was made in those hospitals where documentation of previous oxygen supply costs were available and in which no other factors which could have accounted for a reduced cost of oxygen supply were operational. Six such hospitals, between 40 and 250 beds, recognized an accumulated annual savings of $\$ 183,527$. Urban facilities realized a $34-41 \%$ decrease in oxygen supply costs while some rural facilities realized savings in excess of $50 \%$ of the previous documented cost. Whether such reductions in cryogenic oxygen supply costs will be continued in future years is unknown at this time.

In summary, oxygen concentrators utilizing molecular sieve technology offer a safe, reliable and relatively inexpensive supply of oxygen for hospital medical gas pipeline systems. The development of a CSA standard ${ }^{4}$ for oxygen concentrators will ensure a uniform standard of installation, testing and safe application in Canada.

\section{References}

1 Penny M. Physical and chemical properties of molecular sieves - the pressure absorption cycle. Health Service Estate (HSE) 1987; 61: 44-9.

2 The United States Pharmacopeia, The National Formulary. Rockville Md. United States Pharmacopeial Convention, Inc. 1989 USP XXII NF XVII 1990: 991-2.

3 Nonflammable Medical Gas Piping Systems. CSA Standards Z305.1 - M84. Rexdale: Canadian Standards Association 1984.

4 Medical Oxygen Concentrator Central Supply System: For Use with Nonflammable Medical Gas Piping Systems proposed CSA Standard Z305.6M. Rexdale: Canadian Standards Association 1991.

5 Enzi-Ashi TI, Popworth DP, Nunn JF. Inhalational anaesthesia in developing countries Part II: Anaesthesia 1983; 38: 736-47.

6 Harris CE, Simpson PJ. The "Mini $\mathrm{O}_{2}$ " and "Heathdyne" oxygen concentrators. Their performance and potential application. Anaesthesia 1985; 40: 1206-9.

7 Fenton PM. The Malawi anaesthetic machine. Experience with a new type of anaesthetic apparatus for developing countries. Anaesthesia 1989; 44: 498-503.

8 Donald $S$. Use of the Haloxair apparatus with an oxygen concentrator (letter). Can J Anaesth 1987; 34: 538-9.

9 Swan BB. Oxygen concentrators (letter). Can J Anaesth 1987; 34: 538-9.

10 Arrowsmith $L W M$. Oxygen concentrators for medical gas pipeline systems. Health Service Estate (HSE) 1985; 57: 50-1.

11 Barnes JW. Quality assurance and the oxygen concentrator. Health Service Estate (HSE) 1987; 61: 55-61.
12 Henke I. New technology for oxygen supply. Hospital Engineering Connection 1991; 13: 11-15.

13 Advanced Trauma Life Support Student Manual. Chicago; American College of Surgeons, 1989: 14.

14 Campbell EJM. A method of controlled oxygen administration which reduces the risk of carbon dioxide retention. Lancet 1960; 2: 12-4.

15 Leigh JM. Variation in performance of oxygen therapy devices. Towards the rational employment of the dephlogisticated air described by Priestley. Ann Roy Coll Surg Engl 1973; 52: 234-53.

16 Continuous-Flow Inhalational Anaesthetic Apparatus (Anaesthetic Machines) for Medical Use. CSA Standard Can - Z168.3 - M84. Rexdale: Canadian Standards Association 1984.

17 Friesen RM, Hatton G, Bjornson J. The upgrading and replacement of anaesthetic equipment: a provincial approach. Can J Anaesth 1990; 37: 889-95.

18 Parker CJR. The anaesthetist's experience of PSA oxygen: the problem of argon accumulation in low flow anaesthesia. Health Service Estate (HSE) 1987; 61: 65-70.

19 Williams EL, Benson DM. Helium-induced errors in clinical mass spectrometry. Anesth Analg 1988; 67: 83-5.

20 Halsey $M J$. The physiology of argon, nitrogen and oxygen mixtures and the safety of PSA gas. Health Service Estate (HSE) 1987; 61: 53-5.

21 Cotes JE, Douglas-Jones AG, Saunders MJ. A 60\% oxygen supply for medical use. BMJ 1969; 4: 143-6.

22 Parker CJR, Snowdon SL. Predicted and measured oxygen concentrations in the circle system using low fresh gas flows with oxygen supplied by an oxygen concentrator. $\mathrm{Br}$ J Anaesth 1988; 61: 397-402.

23 Harding $R M$. The role of molecular sieves in modem fighter aircraft. Health Service Estate (HSE) 1987; 61: 50-3.

24 Dobson $M B$. Oxygen concentrators offer cost savings for developing countries. A study based on Papua, New Guinea. Anaesthesia 1991; 46: 217-9. 


\section{Concentrateur d'oxygène: leur place en anesthésie}

Robert M. Friesen MD FRCPC
TABLEAU I Dimensions relatives des tamis moléculaires

Si l'on exclut l'oxygène utilisé à domicile, la plus grande partie de l'oxygène en usage clinique est fourni sous forme liquide. On définit habituellement ce processus comme la distillation cryogénique de l'air. L'oxygène est ensuite fourni à l'utilisateur soit dans des réservoirs ou des cylindres de gaz comprimé. Une source différente d'oxygène, surtout pour les systèmes de conduits hospitaliers existants, est devenu disponible au Manitoba en 1987. La production sur place d'oxygène est rendue possible par l'utilisation d'une technologie basée sur le tamis moléculaire. Un tamis moléculaire permet l'absorption sélective des composantes de l'air. Ce texte passera en revue les processus de génération d'oxygène par les concentrateurs d'oxygène ainsi que les implications de l'approvisionnement en oxygène par les concentrateurs pour les besoins de l'anesthésie et autres services hospitaliers.

L'absorption sélective des composantes de l'air par des substances naturelles, les zéolites, est connue depuis plus de 60 ans. Même si les zéolites sont d'origine naturelle, la recherche industrielle a permis de produire des tamis moléculaires synthétiques de composition beaucoup plus uniforme. Le zéolite a une affinité naturelle pour l'eau qui devient libérée au chauffage. Le mot est d'origine grecque et signifie « pierre qui boût ». Le zéolite synthétique utilisé pour la production de l'oxygène est composé d'un treillis de silice et d'aluminium comprenant un cation supplémentaire pour créer un déficit de charge positive dans la structure. ${ }^{1}$ Les tamis moléculaires pour l'oxygène utilisent du calcium ou du sodium comme cation supplémentaire. Les tamis moléculaires sont disponibles commercialement sous forme de granules agglomérés par un composé inerte.

Les propriétés physiques des gaz qui viennent en contact avec le zéolite (l'adsorbant) déterminent leur adsorption relative à sa surface. Les composantes principales de l'air ont des diamètres moléculaires qui sont suffisamment petits pour qu'elles passent à travers les pores d'un tamis moléculaire (Tableau I). ${ }^{1}$

Le calcium (ou le sodium) comme cation additionnel procure une charge positive nette sur la pore. Les propriétés électroniques des composantes de l'air amenées au tamis moléculaire de zéolite seront donc les déterminants de la force du processus d'adsorption. Ces propriétés incluent la polarisabilité, les mouvements dipolaires et quadripolaires. Les énergies d'adsorption observées ${ }^{1}$ sont

\begin{tabular}{ll}
\hline Pore de zéolite & $4,3 \AA$ \\
Diamètre moléculaire $\mathrm{O}_{2}$ & $3,4 \AA$ \\
Diamètre moléculaire $\mathrm{N}_{2}$ & $3,6 \AA$ \\
Diamètre $\mathrm{Ar}$ & $3,3 \AA$ \\
\hline
\end{tabular}

1 Angstrom $=1 \times 10^{-8} \mathrm{~cm}$.

TABLEAU II Adsorption de molécules par le zéolite

\begin{tabular}{lll}
\hline & & Échelle relative \\
\hline Eau & $\mathrm{H}_{2} \mathrm{O}$ & +++++ \\
Dioxyde de carbone & $\mathrm{CO}_{2}$ & ++++ \\
Azote & $\mathrm{N}_{2}$ & +++ \\
Oxygène & $\mathrm{O}_{2}$ & ++ \pm \\
Argon & $\mathrm{Ar}$ & \pm \\
\hline
\end{tabular}

résumées dans le Tableau II. Le gaz produit est composé essentiellement d'oxygène avec un peu d'argon.

L'efficacité de l'adsorption peut être améliorée par une augmentation modérée de la pression d'opération. La majorité des concentrateurs d'oxygène disponibles sur le marché augmentent leur efficacité en utilisant un cycle d'adsorption par oscillation de pression (PSA). La dynamique de l'adsorption de l'azote et de l'oxygène s'accomplit en mettant en séquence deux colonnes de zéolite dont les cycles sont déphasés pour une valeur de durée d' $1 / 2$ cycle. Ceci assure une production constante d'oxygène. La regénération de chaque colonne de zéolite se fait en évacuant l'azote adsorbée du lit de zéolite à la fin de chaque cycle, et en le chassant brièvement avec une petite quantité de l'oxygène qui vient juste d'être produit. Une alternative à cette regénération consiste en l'application d'une pression négative de courte durée à la fin de chaque cycle.

Les composantes d'un concentrateur d'oxygène comprennent une entrée d'air frais (de dimension appropriée et avec filtre), un compresseur avec refroidisseur d'air et réservoir d'entreposage, et à l'intérieur de l'unité nous retrouvons plusieurs lits de tamis moléculaire au zéolite ainsi qu'un certain nombre d'appareils de contrôle (Figure 1). Un réservoir d'entreposage du gaz produit (source principale) sera habituellement placé à proximité des autres sources d'oxygène comprimé. On s'attend à ce que 


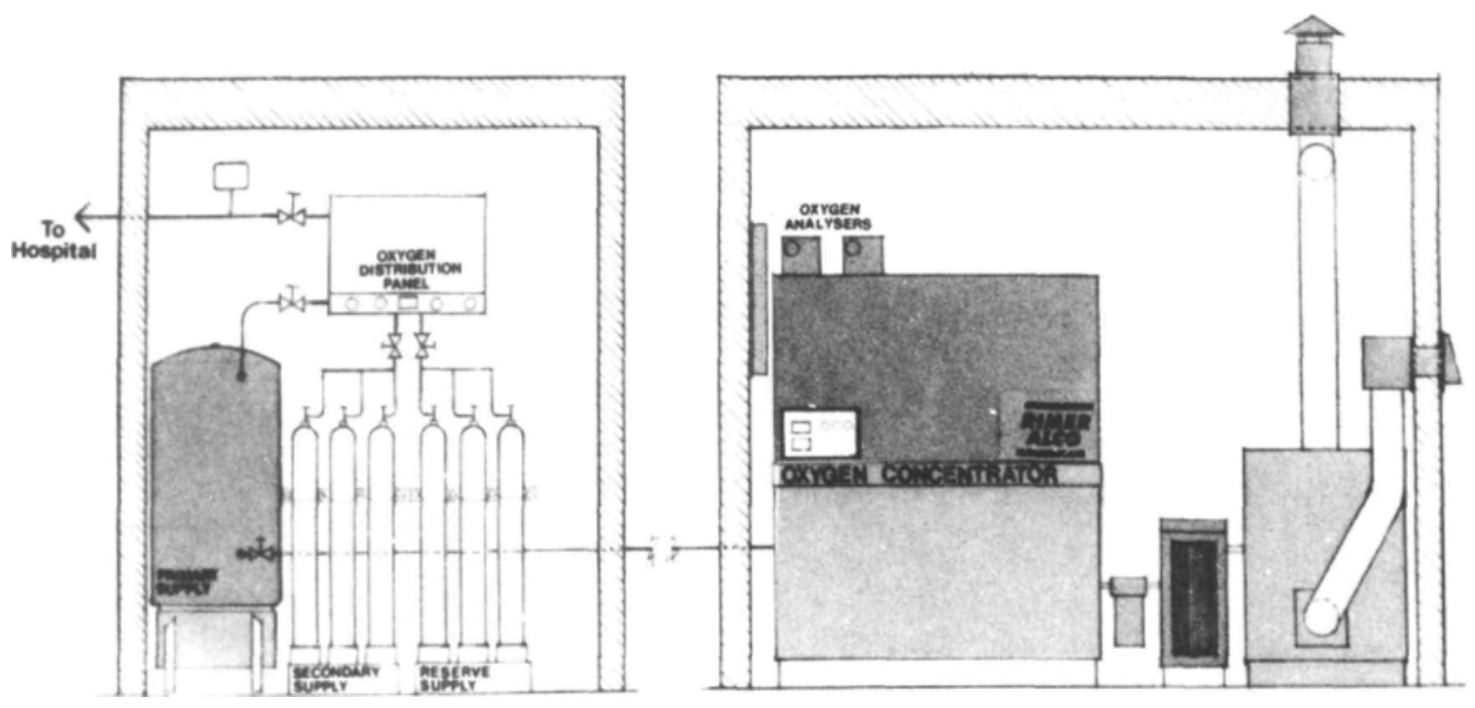

Madical Gas Supply Room
Elevotion

Onveen Concentrator Room

Elevation

FIGURE 1 Installation typique d'un concentrateur d'oxygène.

des raffinements technologiques modifient quelque peu cette configuration.

La United States Pharmacopeia (USP) définit l'oxygène médical comme contenant pas moins de $99 \%$ d'oxygène par volume. ${ }^{2}$ Le gaz produit par le processus de tamisage moléculaire a été lui défini comme de l'oxygène à $93 \%$. Il ne contient pas moins de $90 \%$ et pas plus de $96 \%$ d'oxygène par volume; le reste se compose surtout d'argon et d'azote. L'oxygène à $93 \%$ a été défini de cette façon dans la USP, sur la base des limitations de la technologie du tamis moléculaire jusqu'en 1984. ${ }^{2}$

Le Tableau III montre une comparaison de la composition de l'oxygène $99^{3}$ et de l'oxygène 93 ainsi que les limites maximales pour les traces d'autres substances. L'utilisation de concentrateurs d'oxygène comme source primaire d'oxygène nécessite l'adoption par chaque hôpital de l'oxygène 93 dans son formulaire.

Les normes pour les systèmes de canalisation de gaz médicaux dans les hôpitaux ont déjà été établie par l'Association Canadienne de Normalisation. ${ }^{3}$ Chaque hôpital peut avoir des variations dans son agencement mais tous doivent avoir un approvisionnement primaire, secondaire et de réserve en oxygène (Figure 2). L'importance de l'installation se base sur la dimension de l'institution (nombre de lits), la dispensation de soins aigüs, et la prédiction de la moyenne des demandes de pointe. La source principale d'oxygène est constituée par un approvisionnement primaire et secondaire. L'approvi-
TABLEAU III Comparaison de l' $\mathrm{O}_{2}$ cryogénique et PSA (composants permis)

\begin{tabular}{lll}
\hline & Oxygène 99 (USP) & Oxygène 93 (USP) \\
\hline Oxygène & $\geq 99 \%$ & $>90 \dagger \leq 96 \% *$ \\
Monoxyde de carbone & $5 \mathrm{ppm}$ & $5 \mathrm{ppm}$ \\
Dioxide de carbone & $100 \mathrm{ppm}$ & $100 \mathrm{ppm}$ \\
Méthane (ou équivalent) & $100 \mathrm{ppm} \ddagger$ & $25 \mathrm{ppm}$ \\
Protoxyde d'azote & $5 \mathrm{ppm}$ & $5 \mathrm{ppm}$ \\
Agents anesthésiques & $0.1 \mathrm{ppm}$ & $0.1 \mathrm{ppm}$ \\
Particules d'huile & $1 \mathrm{mg} \cdot \mathrm{m}^{-3}$ & $1 \mathrm{mg} \cdot \mathrm{m}^{-3}$ \\
Dioxide de soufre & $1 \mathrm{ppm}$ & $1 \mathrm{ppm}$ \\
Hydrocarbones halogénés & & \\
$\quad$ totaux & $5 \mathrm{ppm}$ & $5 \mathrm{ppm}$ \\
Autres composants ou & & \\
contaminants & $1 / 2 \mathrm{TLV}$ & $1 / 2 \mathrm{TLV}$ \\
\hline
\end{tabular}

*Balance argon et azote.

†Norme de l'ACNOR Z305,6 : performance minimale des concentrateurs d $\mathrm{O}_{2}: \mathrm{O}_{2} \geq 93 \%$ par volume.

ppm - parties par million.

‡TLV-Limite-seuil deffinie par l'American Conference of Governmental and Industrial Hygienists (ACGIH).

sionnement primaire est utilisé dans la plupart des circonstances où une source d'oxygène centrale est requise. Lorsqu'il y a période de pointe, l'approvisionnement secondaire de l'hôpital peut être utilisé et ceci n'est pas une circonstance anormale. On ne recommande cependant pas une utilisation excessive de la source secondaire 


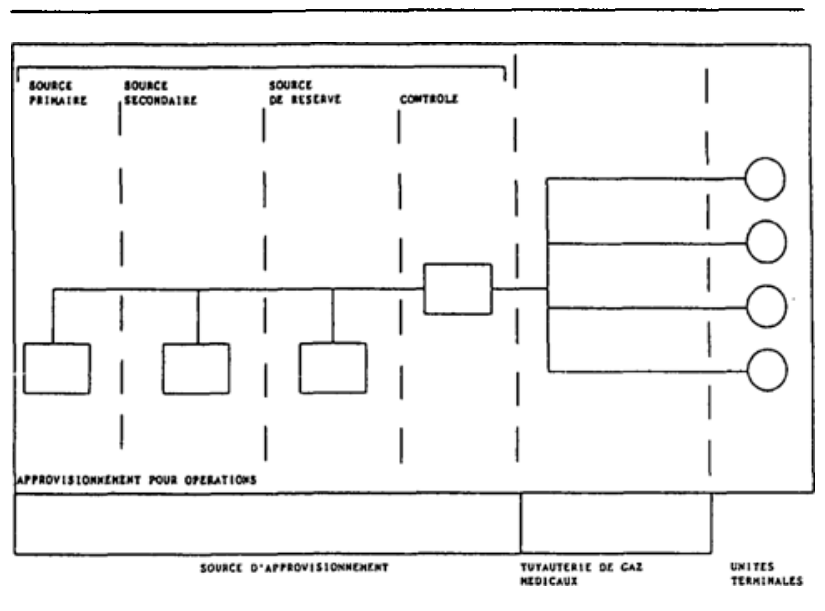

FIGURE 2 Système hospitalier de canalisations de gą médicaux.

d'oxygène. L'approvisionnement de réserve s'utilise seulement s'il y a une panne.

Actuellement l'expérience canadienne avec les concentrateurs d'oxygène se limite à leur utilisation comme source primaire d'oxygène (Figure 1). Dans la plupart des cas, le concentrateur d'oxygène est ajouté à un système déjà existant de canalisations. L'addition d'un concentrateur à un système déjà en place augmente la source d'approvisionnement en oxygène. Les normes actuelles de l'ACNOR pour les systèmes conventionnels de tuyauterie de gaz médicaux ${ }^{3}$ sont comparées dans le Tableau IV avec celles suggérés ${ }^{4}$ pour les établissements de santé qui utilisent un concentrateur d'oxygène comme source primaire d'approvisionnement.

L'expérience canadienne en utilisation de concentrateurs d'oxygène pour l'approvisionnement en oxygène médical est relativement limitée lorsqu'on la compare à celle d'autres pays. ${ }^{5-9}$ Les premiers modèles de concentrateurs d'oxygène ne pouvaient fournir le volume, les débits ou la régularité d'approvisionnement en oxygène que la technologie actuelle nous permet. Il y a un certain nombre de champs d'intérêts et possiblement d'inquiétude pour les anesthésistes qui pratiquent dans un hôpital où un concentrateur d'oxygène sert de source d'approvisionnement primaire.

L'expérience internationale ${ }^{10-12}$ et locale a montré que les concentrateurs d'oxygène peuvent être une source fiable d'approvisionnement en oxygène. Au Manitoba, on a démontré que les concentrateurs d'oxygène peuvent donner un approvisionnement continu d'oxygène d'une concentration égale ou supérieure à $95 \%$. Le résidu est composé d'argon et de traces d'ázote. Une paire d'analyseurs d'oxygène surveille continuellement la production des concentrateurs d'oxygène et enclenche le débranchement du concentrateur du système de canalisations de l'hô-
TABLEAU IV Approvisionnement hospitalier en $\mathrm{O}_{2}$

\begin{tabular}{llc}
\hline & ACNOR Z305,I & ACNOR Z305,6* \\
\hline $\begin{array}{c}\text { Approvisionnement } \\
\text { primaire }\end{array}$ & $\pi$ & $2 \times$ débit moyen \\
$\begin{array}{c}\text { Approvisionnement } \\
\text { secondaire } \ddagger\end{array}$ & ก & $\begin{array}{c}2 \text { jours de demande } \\
\text { moyenne } \dagger\end{array}$ \\
Réserve $\ddagger$ & $\begin{array}{c}\text { Demande moyenne } \\
\text { d'une journée }\end{array}$ & $\begin{array}{c}\text { Demande moyenne } \\
\text { pour } 1,5 \text { jours }\end{array}$ \\
\hline
\end{tabular}

*Proposition préliminaire

$\nmid$ Les conditions locales (remplacement, éloignement) peuvent dicter des sources secondaires plus importantes.

‡Composées d'oxygène 99.

IS Selon la dimension de l'établissement.

pital si la concentration de l'oxygène produit diminue. L'analyseur d'oxygène Servomex modèle 571 utilisé dans les installations du Manitoba a une précision de l'ordre de $\pm 0,3 \%$ pour l'oxygène.

La norme de l'ACNOR Z305, $1^{3}$ concerne la spécificité des canalisations de gaz médicaux. L'oxygène 99 et l'oxygène 93 sont deux préparations pharmaceutiques différentes selon l'USP. ${ }^{2}$ Comme les sources d'approvisionnement secondaire et de réserve d'un hôpital qui utilise un concentrateur d'oxygène sont approvisionnées en oxygène 99, il y aura un certain mélange des deux gaz. L'expérience a démontré que ceci n'avait pas d'importance clinique. Une décision de Santé et Bien-Être Canada sur la justification de mélanger de l'oxygène 93 et de l'oxygène 99 supporte aussi une telle pratique. Comme mentionné plus haut, la surveillance de la concentration d'oxygène en bout de ligne est importante. Les procédures d'évaluation et de certification doivent être modifiées pour tenir compte de la présence d'un concentrateur. ${ }^{4}$

La majorité des traitements à base d'oxygène sont dictés par les réponses des patients et non pas par des changements mineurs dans la concentration inspirée en oxygène. L'American College of Surgeons définit une concentration d'oxygène inspirée adéquate pour la réanimation avancée en traumatologie comme supérieure à $85 \% .^{13}$

Campbell ${ }^{14}$ et Leigh ${ }^{15}$ ont décrit les prérequis pour une thérapie stable et à haut volume par concentration d'oxygène. Le Ventimask ${ }^{\circledR}$ à oxygène \#3 manufacturé par Vickers Air-Shields utilise le principe d'entraînement par venturi avec un débit d'oxygène déterminé pour administrer une concentration spécifique d'oxygène à un patient en respiration spontanée. Le Tableau $V$ résume les effets de l'utilisation des sources d'oxygène autres que l'oxygène 99 sur le mélange final obtenu. La variation de la concentration d'oxygène administrée se maintient dans les limites de $1 \%$ proposée par Campbell. ${ }^{14}$

Les machines d'anesthésie modernes certifiées par l'ACNOR $^{16}$ ne sont pas touchées négativement lors- 
TABLEAU V Effet des changements de concentration d' $\mathrm{O}_{2}$ dans la source de gaz sur la performance calculée du Ventimask - $3^{\circ}$

\begin{tabular}{llllll}
\hline & & \multicolumn{3}{l}{$\% O_{2}$ calculé la l'inspiration } \\
\cline { 5 - 6 }$\% d^{3} \mathrm{O}_{2}$ visé & Débit en $\mathrm{O}_{2}{ }^{\prime}$ & Débit total & $O_{2}(99)$ & $O_{2}(95)$ & $O_{2}(93)$ \\
\hline 24 & 3 & 78 & 24 & 23,8 & 23,8 \\
28 & 6 & 66 & 28 & 27,7 & 27,6 \\
35 & 12 & 67 & 35 & 34,2 & 33,9 \\
\hline
\end{tabular}

'Débit selon spécifications du Ventimask -3 .

${ }^{2}$ Débit total $=\mathrm{O}_{2}+$ débit entraîné.

${ }^{3} \% \mathrm{O}_{2}$ inspiré calculé $=$ contenu en $\mathrm{O}_{2} /$ volume total.

${ }^{4} \mathrm{FIO}_{2}$ assumé dans l'air $=0,21$.

qu'approvisionnées par un concentrateur d'oxygène. Les manufacturiers Ohmeda, Drager et Penlon ont été avisés de l'utilisation de concentrateurs d'oxygène au Manitoba, avant la demande de soumission pour le programme de mise à jour des machines d'anesthésie du Manitoba. ${ }^{17}$ Les machines d'anesthésie peuvent utiliser un modèle quelconque de proportionneur de protoxyde d'azote et d'oxygène pour prévenir l'administration par inadvertance d'un mélange hypoxique au patient. L'apport d'oxygène 93 plutôt que l'oxygène 99 au contrôleur de rapport d'oxygène de North American Drager ou au système Ohmeda Link-25 ne produit pas de mélange inspiré hypoxique. Le système Ohmeda Link-25 en fait augmente le débit d'oxygène, si celui de protoxyde d'azote est augmenté par erreur, pour maintenir un rapport de débit protoxyde/oxygène de $3: 1$.

La viscosité de l'argon est semblable à celle de l'oxygène mais le gaz est plus dense $\left(1,78 \mathrm{~kg} \cdot \mathrm{m}^{-1}\right.$ versus 1,43 $\mathrm{kg} \cdot \mathrm{m}^{-1}$ ). ${ }^{18}$ La présence d'argon (moins de $7 \%$ ) dans l'oxygène ne change pas ses caractéristiques de débit.

Les technologies d'analyse par infra-rouge, cellule galvanique ou paramagnétique ne sont pas touchées par la présence d'argon. L'analyse par spectrométrie de masse des gaz anesthésiques peut demander un réajustement du programme pour tenir compte de la concentration augmentée d'argon. Ceci ressemble à l'expérience antérieure de Williams et Benson ${ }^{19}$ avec l'hélium.

L'argon est un gaz anesthésique à des concentrations absolues variant entre 15,2 et 16,9 atmosphères. ${ }^{20}$ En comparaison, l'oxygène est potentiellement convulsivant à trois atmosphères absolus et anesthésique à une pression absolue de 15 atmosphères. Il n'y a pas d'effets physiologiques connus à une exposition courte ou longue à une concentration faible d'argon. ${ }^{20,21}$

Les techniques à bas débit ou en circuit fermé représentent un problème particulier lorsqu'il y a approvisionnement d'oxygène par technologie de tamis moléculaire. L'accumulation d'argon se produit comme conséquence de la captation sélective d'oxygène. Les déterminants princi- paux de l'accumulation d'argon sont le débit de gaz frais du circuit et le taux de consommation d'oxygène par le patient. ${ }^{18,22} \mathrm{~L}$ 'administration concomitante de protoxyde d'azote complique ce processus. Une fois de plus on doit insister sur l'analyse continue de la concentration d'oxygène dans le circuit.

Des données non publiées provenant d'hôpitaux du Royaume Uni, de l'armée américaine et de Reimer Alco, (un des nombreux manufacturier de concentrateurs d'oxygène) ainsi que des données publiées, ${ }^{11}$ montrent que le tamis moléculaire au zéolite est très efficace pour filtrer la plupart des polluants de l'air. Les contaminants possibles ou les sources évaluées comprennent les échappement de voitures, les vidanges de moteurs à réaction, ${ }^{21}$ l'oxyde d'éthylène, le dioxide de soufre, de nombreux hydrocarbures ainsi que les agents habituellement réservés pour la guerre chimique. Les agents chimiques introduits dans l'entrée d'air des concentrateurs d'oxygène évalués comprennent des outils de guerre chimique (gaz moutarde, sarin, cyanure d'hydrogène, chlorure cyanogène) ainsi que le dimethyl méthylphosphonate, le chlorure de méthyl et le perfluoroisobutylène. Le tamis moléculaire n'a permis à aucun de ces agents de filtrer et contaminer le gaz produit. On a suggéré cependant qu'une contamination massive du tamis moléculaire par des agents qui y adhèrent de façon irréversible va produire une diminution d'efficacité du tamis. Cette condition devrait être révélée par l'analyse continue de l'oxygène.

La raison principale qui explique le perfectionnement des concentrateurs d'oxygène par tamis moléculaire a été le manque de fiabilité de l'approvisionnement, ainsi que le coût de l'oxygène dans plusieurs endroits du globe. Les concentrateurs d'oxygène sont actuellement utilisés pour fournir de l'oxygène de qualité médicale dans un large spectre d'applications. Quelques unes de celles-ci comprennent les applications militaires (hôpitaux mobiles, avions de chasse, ${ }^{23}$ vaisseaux de la marine) ainsi que des établissements médicaux éloignés à travers le monde et plus récemment en Amérique du Nord. Sur le plan écono- 
TABLEAU VI Résumé des coûts : concentrateurs d'oxygène au Manitoba

\begin{tabular}{ll}
\hline Hôpitaux & 22 \\
Dimension des hôpitaux & $11-152$ lits \\
Nombre total de lits & 929 \\
Capitalisation/centre & $22265 \$-342985 \$$ \\
Période d'auto-financement $\dagger$ & $1,6-5,0$ ans $(3,64)$ \\
Épargnes projetées (13 ans)* & $6463872 \$$ \\
\hline
\end{tabular}

*Assume des augmentations de $6 \%$ des coûts annuels d'opération et un marché stable pour l'oxygène cryogénique.

†Période moyenne d'autofinancement: 3.6 ans.

mique les concentrateurs d'oxygène sont considérés sous un oeil très favorable. ${ }^{12,24}$

Les augmentations excessives dans le coût d'approvisionnement en oxygène au milieu des années 1980 ont poussé la province du Manitoba à rechercher des sources alternatives d'oxygène. Avec la coopération d'un manufacturier et d'un fournisseur local de technologie de concentration d'oxygène (Rimer Alco, Morden, Manitoba), la Commission des Services de Santé du Manitoba a entrepris un projet pilote. Il y a actuellement 22 hôpitaux dans la province du Manitoba dont la source primaire d'oxygène est un concentrateur. Le Tableau VI résume les coûts impliqués et les économies projetées de ces installations.

Un bénéfice supplémentaire amené par l'installation de concentrateurs d'oxygène se retrouve dans la compétition plus importante au niveau du marché d'approvisionnement en oxygène. Les services d'approvisionnement des hôpitaux ont remarqué des diminutions importantes de prix dans les soumissions pour l' approvisionnement d'oxygène 99 sous forme comprimée ou liquide, lorsque ces services ont envisagé de soumettre des soumissions pour l'installation de concentrateurs d'oxygène. On a effectué une analyse dans les hôpitaux où l'on pouvait documenter les coûts antérieurs d'approvisionnement en oxygène, et dans lesquels aucun autre des facteurs qui aurait pu rendre compte de la diminution des coûts d'approvisionnement était en force. Six de ces hôpitaux, de 40 à 250 lits, ont noté des épargnes annuelles accumulées de $183527 \$$. Les hôpitaux urbains ont réalisés des économies de 34 à $41 \%$ dans le coût de l'oxygène, alors que certains centres ruraux ont réalisé des économies au-delà de 50\% par rapport aux coûts antérieurs. Il reste à savoir dans le futur si de pareilles diminutions des coûts d'approvisionnement en oxygène cryogénique se continueront dans le futur.

En résumé, les concentrateurs d'oxygène utilisant la technologie du tamis moléculaire offrent un approvisionnement sûr, fiable et relativement peu coûteux en oxygène pour les systèmes de tuyauterie hospitalière. Le développement de normes de l'ACNOR ${ }^{4}$ pour les concen- trateurs d'oxygène assurera un niveau uniforme d'installation, d'évaluation et d'application sécuritaire au Canada.

\author{
Références \\ (Voir page R84)
}

